\section{Maastricht Treaty undemocratic}

SIR - Your leading article "Can Europe ever be made to function?" (Nature 364, $467 ; 1993)$ states that "[the] chief goal [of the Maastricht Treaty] is . . . to replace all 12 European currencies by a single European currency". Chief goal? The "Treaty on European Union" contains seven "titles', six of them of substantive importance. Among many purposes, only one could be called "chief": that declaimed by the treaty's name, and Title I, the establishment of a (political) European Union. This is a vastly larger project than a single currency, although monetary union would no doubt so tie the hands of national governments that any pretence of national independence would rapidly be seen to be just that. Currency union, the subject of only parts of Title II of the treaty, is thus a means, but not the end.

The treaty declares as a fundamental constitutional principle the agglomeration of political power into the hands of European Community (EC) institutions (the acquis communautaire of Article B - it is surely significant that no English translation of this phrase has been found). It is also clear that the executive and legislative apparatus exercising that power will remain on a nondemocratic basis (notwithstanding the byzantine, and merely incremental, reforms of decision-making in Articles 189 (a-d) (Treaty of Rome as amended under Article $\mathrm{G}$ of Maastricht)). European citizens thus face surrender both of national sovereignties and also, more importantly, surrender of parliamentary democracy.

You excuse the failure of the timetable for monetary union as a project that got too far ahead of "general cohesion", and you describe both as "excellent objectives". But why should one find the objectives excellent? The treaty is a fundamental constitutional document in which democracy has been almost forgotten. You call for EC institutions to be placed on a "more secure and rational foundation"; yet they are already all too secure, and, for the purpose of dragging the continent into a nondemocratic superstate, all too rational. The fundamental flaws of all the European treaties and institutions, unacceptable to millions, but which you fail to identify, are the absences of (1) a thorough-going democratic constitution, and (2) clearly drawn limits to EC jurisdiction.

To those of us who still believe in the vote and representative democracy as the only satisfactory basis yet found for civilized government, the recent setbacks for monetary union will be seen as a glimmer of hope; there is now some prospect that the glue intended to bind unwilling subjects to the political objectives of the treaty will come permanently unstuck.
From such a viewpoint, monetary union will not be seen in a different light until democracy replaces bureaucracy and technocracy as the executive and legislative basis of the EC. That, however, requires standing the Maastricht Treaty completely on its head.

To Nature readers from the United States, whose founding fathers (unlike those of the EC) cared deeply about democracy, your sentiments might appear, in the light of the actual treaty text, distinctly peculiar. To readers from newly democratic European countries, they ought also to be troubling: the democratic criteria for admission should not delude them into supposing that the EC will itself be democratic. It is significant that (in the United Kingdom at any rate) only bitter opponents of the treaty encouraged us to read it. I began this letter supposing that your leader-writer had not; some proponents in the government even admitted to this. Reading it, belatedly, was an eye-opener for me; I urge readers in any country currently considering EC membership to do the same, as a vital duty to themselves and their countrymen.

\section{E. J. Fordham}

\section{Hemingford Road,}

Cambridge CB1 $3 B Y$, UK

\section{Not so free trade}

SIR - Europe is now without frontiers. There is free passage of goods and people across national borders. As this is the case, I would like to ask the manufacturers of scientific equipment and consumables why I have to pay a premium of more than 100 per cent on some goods for working in Italy? A number of manufacturers refuse to supply goods across national boundaries, referring me back to the local distributor. In one case, the local distributor charged a sterling equivalent of $£ 370$ when the price in England was $£ 165$. Furthermore, the local distributor did not want to send my order to the parent company in the United States until he had received a few other orders, necessitating a wait of well over a week if the required additional orders did materialize, and well over two if they did not. The English supplier had the product in stock and would have provided it immediately had he been allowed to do so. I am left in the position of having to pay considerably more for a service that is significantly worse.

I have been told that Italy is a special case because collecting payments can be difficult. Although this is true for some institutions, it is not so for all, and problems of this sort could be provided for within the terms of a contract of sale. It also does not explain why the prices in other European countries that do not have this problem remain considerably higher than those in the United Kingdom.

Would it not be to the benefit of both researcher and company if the supply of consumables and equipment was provided by single central European warehouses? This would guarantee a single uniform European price and a stock larger than that which could be carried by any individual national distributor. It is difficult to see why the efficient distribution service that exists in America could not be introduced into a Europe without frontiers. Failing this, the cosy local distributor arrangements should be terminated, allowing a scientist to shop around and purchase his reagents from the cheapest and best stocked European supplier even among the different distributors of a single producer.

\section{Andrew Bradbury}

Area di Ricerca,

Padriciano 99,

Trieste 34012, Italy

\section{Palmer Station}

SIR - On your recent article, "NSF hangs out wary welcome sign" (Nature 361, 106; 1993), I would like to correct Jeffrey Mervis's statement that "visitors do not get a guided tour" of Palmer Station in Antarctica. Organized guided tours of Palmer Station have been provided by station personnel since 1988 . The station tour is divided into two parts. The first is an outside tour that leads visitors, in groups of 25, though the centre of the station and ends at a display located just outside the Aquaria Laboratory. The second involves entering the primary building, BioLab, as it is called locally, and walking up to the kitchen and dining area. Refreshments are served and visitors have the opportunity to meet researchers, station support staff and the NSFsponsored visiting artist. Each segment of the tour is 30 minutes long.

Visitors with special interests are generally accommodated if they request to see a part of the station that is not included in the regular tour. Ham radio operators are shown our communications centre and visiting physicians see the dispensary and $\mathrm{X}$-ray room.

A four-hour visit requires 40 labour hours to support. Station personnel volunteer to serve as tour guides. The role of last year's National Park Service representative was not to develop a new programme. The goal was to observe the existing tour programme and make recommendations for improvements.

\section{Ann Peoples}

Operations Manager, Palmer Station,

Antarctic Support Associates,

61 Inverness Drive East, Suite 300 ,

Englewood, Colorado 80112, USA 